\section{Shaporev V., Pitak I., Pitak 0., Briankin 5.}

\title{
INVESTIGATION OF THE FUNCTIONING OF A VORTEX TUBE IN SUPPLY OF DISPERSE FLOW (GAS - DUST PARTICLES) TO THE TUBE
}

\begin{abstract}
Досліджено функціонування вихрових труб для прочесу сухого очищення вихлопних газів від аерозолю, в яких аеродинамічна ситуація призводить до виникнення ефекту Ранка. Досліджено процес «сухого» пилоочищення $і$ його теоретичне обгрунтування з урахуванням параметрів: геометрії та конструкції апарату; вхідних параметрів газового потоку і хімічного складу часток; можливості хімічної взаємодї з газовими компонентами.
\end{abstract}

Ключові слова: сухе очищення вихлопних газів від аерозолю, ефект Ранка, вихлопна труба.

\section{Introduced}

Modern technology for dedusting technological and aspiration gas emissions is based on combined technological gas purification schemes, including dry and wet dust collectors. Gas emissions contain a dispersed phase (dust) up to $200 \mathrm{~g} / \mathrm{Nm}^{3}$, as well as toxic gaseous substances $\left(\mathrm{CO}, \mathrm{NO}_{x}\right.$, $\mathrm{SO}_{x}, \mathrm{HCl}$, etc.) in relatively small concentrations (up to $150 \mathrm{mg} / \mathrm{Nm}^{3}$ ). The above schemes are especially common in cases where technological gas emissions have a high temperature (more than $373 \mathrm{~K}$ ) [1, 2].

At the stage of dry dust collection, cyclones and motorcolumns are used as apparatus. At the wet purification stage, apparatuses are used in which purification is based on washing the gas with a liquid (water) with a more developed contact surface of the aerosol particles with the liquid and intensive mixing of the phases. The latest devices include: packed scrubbers, centrifugal scrubbers, Venturi tubes, foam machines and others [1, 2].

Disadvantages of devices and processes for purification gas emissions at each stage are known [1-3]. Cyclones of various designs are not capable of capturing dust particles smaller than $20 \mu \mathrm{m}[4,5]$. Important is the question of the most effective forms of the cyclone and its equipment (bunker, gas inlet-outlet, etc.) are solved more empirically $[4,5]$. In the second stage, wet dust collectors are complex in design, require significant energy costs, and also require the use of water depending on the type of dust collector to $10 \mathrm{l} / \mathrm{Nm}^{3}$. As a result of operation, significant amounts of industrial effluents are generated, which must be disposed of using additional equipment [1-3].

At present, development of the theory of centrifugal capture of solid particles from gas emissions is considered to be one of the promising directions of research on technology and apparatus for dedusting technological and aspiration gas emissions. Also promising direction is development of scientific developments in terms of hardware design [4-7]. This is done to improve the efficiency of dry purification of gas emissions. All improvements in terms of hardware design can be divided into the following three groups. The first group is when a dusty flow is fed into the apparatus (inlet tube). The second group is the body of the apparatus itself (cyclone, vortex tubes, vortex chambers, gas centrifuges operating due to the action of Lorentz forces, when radial electric current flows across the lines of force of the magnetic field). The third group is the removal of cleaned air from the apparatus (the outlet of clean air) and dust (a bunker and an outlet for the dust extracted from it).

According to the above classification, it is obvious that the type and design features of the apparatus are the main one. This is due to the fact that the latter determine the flow conditions of the gas flow (hydrodynamics, thermodiffusion distribution of fractions in the gas flow, etc.) and, accordingly, the efficiency of dust removal. According to modern ideas and practice, high efficiency of dust collection can be achieved by using centrifugal inertia apparatus in which vortex swirling flows are realized $[8,9]$. In such flows, the total separation coefficient of gas molecules and particles is a consequence of several processes:

- centrifugal separation;

- thermodiffusion separation;

- by increasing the spatial heterogeneity in the course of the chemical reaction; due to the formation of relatively large particles (molecular clusters and agglomeration of dust) in the reaction zone.

The main role in this case is the value of the coefficient in the separation inlet, which exponentially depends on the relative mass difference and the ratio of the kinetic energy of rotation in the thermal energy of the gas flow centralized parameter:

$$
\theta=M v / T
$$

where $M$ - the mass of molecules and particles in the gas flow; $v$ - drift velocity of the gas flow; $T$ - the thermodynamic temperature.

The exponential dependence indicates that an almost small increase in this parameter leads to a significant increase in the separation degree. If the dispersion gas flow rotates intensely, the particles of the aerosol (dust) have a greater mass than the molecules of the carrier gas and 
will move along the walls of the apparatus. In the case of lighter gas molecules - they will be in the inlet of the working chamber.

Redistribution of particles with different masses is a process of diffuse, and characteristic separation time is inversely proportional to the diffusion coefficient, which varies with temperature as $1 / \sqrt{T}$. Therefore, the temperature gradients that arise in swirling flows, as well as the temperature of the carrier organization, will affect the redistribution of masses along the radius of the chamber and the distribution coefficient.

Proceeding from the foregoing, it becomes clear the possibility of influence due to the flow of chemical reactions in the flow and the formation of relatively large dust particles due to agglomeration.

From the list of types of apparatus for the process of dry exhaust gas purification from aerosol, given earlier in the text, the most effective is the vortex tube. Such conclusion is made because in it the aerodynamic situation leads to the occurrence of Rank effect. This is the effect of redistribution of the total energy in the rotating flow, depending on the corresponding change in the dynamic structure of the flow, depending on the energy structure. This aerodynamic situation arises with the mobility of the two-phase flow being wrapped at $\operatorname{Re} \geq 10^{5}[8,9]$.

The study of the functioning of vortex tubes, in which the working gas is an aerosol (gas-solid system), are not available in the literature, except for general instructions on the possibility of using vortex tubes for this purpose [10].

The foregoing stipulates the urgency of studies of the processes of «dry» dust removal and their theoretical justification, taking into account the above-mentioned influential parameters. These parameters include:

- geometry and design of centrifugal apparatus;

- influence of the input parameters of the gas flow and the chemical composition of dust particles on their distribution in the flow;

- possibility of agglomeration;

- possibility of chemical interaction with gas components, which are part of the gas flow except dust particles.

\section{The object of research and its technological audit}

The object of research is the functioning of the vortex tube when a homogeneous gas is fed into it. Based on the well-known literature sources [11-13], let's consider the effect of energy separation, the nature of the temperature field, the structure of the flows in different sections of the vortex tube. Fig. 1 is a schematic diagram of a vortex tube.

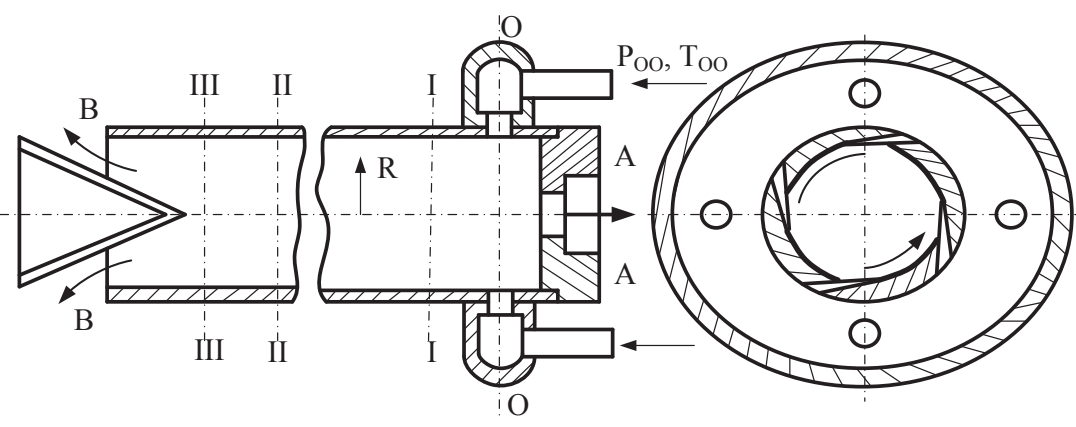

Fig. 1. Schematic diagram of a vortex tube
Gas is supplied to the vortex tube by nozzles under pressure (intersection $0-0$ in Fig. 1) and creates a flow inside the tube. On one side (in section A-A), the flow leaves through the hole located on the axis of the tube. On the opposite side of the tube, the outlet is made in the form of an annular gap located on the periphery (intersection B-B). As studies show, the gas flows through the central hole in section $\mathrm{A}-\mathrm{A}$ and has a much lower braking temperature than at the periphery in section $\mathrm{B}-\mathrm{B}$. The lowest braking temperature on the axis corresponds to the intersection I-I. Consequently, a temperature distribution of the gas flow passes through such tube, and a cooled gas flows through the central hole. The velocity profiles in different cross sections show that the flow is subject to intensive flow reforming: the velocities to the periphery decrease intensively to the intersections III-III, and in the core on the axis increase somewhat. The non-uniform distribution of velocities along the radius causes intensive dissipation of mechanical energy, internal heat release and uneven distribution of the braking temperatures. Specific cooling capacity $\mathrm{q}_{\mathrm{c}}$ in the tube operation is the amount of heat attributed to the mass of the flowing gas $M_{a}$, which is taken away from the cold flow of $M_{c}$ and, accordingly, transferred to the hot flow of $m_{h}$ :

$$
\begin{aligned}
& q_{C}=B C_{p} \Delta T_{A C}=(1-B) C_{p} \Delta T_{H} ; \\
& B=\frac{m_{C}}{m_{A}} \geq \frac{Q_{C}}{Q_{A}} \cdot \Delta T_{A C}=T_{A A}-T_{A C} ; \\
& \Delta T_{H}=T_{A H}-T_{A A} .
\end{aligned}
$$

As can be seen, the function $q_{c}(B)$ has a maximum at $B=0.6$. The working range of vortex tubes, based on the literature data [11-13], is considered to be a range from 0.2 to 0.8 . For a comparative evaluation of the quality of vortex tubes, the coefficient of temperature efficiency is used for cooling the gas:

$$
\eta=\Delta T_{A C} / \Delta T_{O S}
$$

where $\Delta T_{O S}$ - the temperature difference in the isentropic expansion process from the initial parameters with the parameters of the cold flow at the outlet.

As is known from the sources [11-13], in the middle of the vortex tube there are two forms of swirling flow. The profile of the surrounding reverse flow is close to the quasi-solid type of rotation (zone $\mathrm{I}-\mathrm{O}-\mathrm{A}$ ), and the peripheral zone (intersection II-III-B) - to the quasipotential rotation type.

An intensive redistribution of the energy and temperature of the flow is observed in the $\mathrm{I}-\mathrm{O}$ zone. It is established in $[14,15]$ that when introducing an aerosol (particles of dust or liquid droplets) in a gas flow, the latter change the velocity level, but do not change the character of the velocity distribution. In addition, the change in the profiles of tangential velocities has practically no effect on the trajectory of the motion of the aerosol particle, if the average velocity level remains constant [14, 15].

Thus, it can be pointed out that the phenomena described above, which are observed in vortex tubes when a homogeneous gas is fed, will also be observed 
when a dispersed flow is fed into it. Therefore, the calculated separation coefficient of particles and gas molecules in the vortex tube can be much larger than, for example, in cyclones.

\section{The aim and objectives of research}

The aim of research is study of dust collection process in vortex tubes and determination of the efficiency of the dry gas purification process; advisability of using vortex tubes as highly efficient dust collectors for dry purification of gases. This is done to improve the efficiency of dry purification of gas emissions.

To achieve this goal, it is necessary:

1. To investigate the process of dry dust removal of exhaust gases produced by zinc white after melting furnaces of metallic zinc in a vortex tube.

2. It is experimentally established that the agglomeration of aerosol particles is formed in a vortex tube in a zone of quasi-solid rotation.

3. To bring the possibility of catalytic destruction of gas impurities $\left(\mathrm{CO}, \mathrm{NO}_{\mathrm{x}}, \mathrm{SO}_{2}\right)$.

4. To bring the advantages of the vortex tube as a separator above the cyclones.

\section{Research of existing solutions of the problem}

Among the main directions aimed at eliminating the problem of dedusting technological and aspiration gas emissions that were found in the resources of world literature, the following can be singled out:

- modern technology for dedusting technological and aspiration gas emissions is common when technological gas emissions have a high temperature [1, 2];

- as a result of the operation of the dedusting apparatus, significant amounts of industrial effluents are generated, which must be disposed of using additional equipment [1-3];

- high efficiency of dust collection can be achieved

by using centrifugal inertial devices $[8,9]$;

- the aerodynamic situation in the vortex tube leads

to the occurrence of Rank effect [8,9].

The effect of the energy separation, the nature of the temperature field, and the structure of the flows in different sections of the vortex tube are considered [11-13].
The study of the functioning of vortex tubes, in which the working gas is an aerosol (gas-solid system), is lacking in the literature, except for general instructions on the possibility of using vortex tubes for this purpose [10, 18].

Thus, the phenomena that are observed in the vortex tubes when a homogeneous gas is fed will also be observed when a dispersed flow is fed into it. Therefore, the calculated separation coefficient of particles and gas molecules in the vortex tube can be larger than in cyclones.

\section{Methods of research}

Experimental studies of the process of dust collection in a vortex tube were carried out on the operating production line for the production of dry zinc white. The method and equipment of production by basic parameters corresponds to known technologies, for example [16]. The source of dustiness and gas content of exhaust gaseous products is a muffle furnace for melting of metallic zinc. The capacity for gas emissions was $1500-3000 \mathrm{Nm}^{3}$ /year. The pressure at which the exhaust gases were fed into the vortex tube was $1.2-1.5 \cdot 10^{5} \mathrm{~Pa}$, the temperature of the gas flow at the inlet was $793-823 \mathrm{~K}$. The structure of the vortex tube is shown in Fig. 2, and the hot gas outlet and the separation part are shown in Fig. 3. The largest diameter of zone 5 (Fig. 2) was $250 \mathrm{~mm}, l_{H}-$ $3000 \mathrm{~mm}$

Parameter $B=Q_{C} / Q_{A}$ during the studies was changed in the interval $0.3<B<0.7$, that is, the value of «d» in the cold gas outlet chamber was changed. The value of $l_{H}$ was $900 \mathrm{~mm}$. As an annular swirler (Fig. 2, pos. 1), replaceable rings with 8 tangential slits $0.1 \cdot 10^{-3} \mathrm{~m}$ in width, $1 \cdot 10^{-2} \mathrm{~m}$ in height with 16 round tangential apertures $0.3 \cdot 10^{-2} \mathrm{~m}$ in diameter and with 8 tangential supersonic nozzles $d_{k p}=0.3 \cdot 10^{-2} \mathrm{~m}$. All the rings had a diameter of $0.4 \mathrm{~m}$, a width of $0.015 \mathrm{~m}$, the slits and holes were evenly distributed along the perimeter of the rings. The outlet from the cleaned gas tube (Fig. 3, item 17) was such that the area of the outlet ( $D_{1}$ in Fig. 3$)$ was 10 times larger than the computed hole area ( $d$ in Fig. 1), and the area $\left(D_{3}\right.$ in Fig. 3$)$ more than 5 times the number of compiled areas $\left(d+D_{1}\right)$. Fig. 2,3 show the temperature measurement points $T_{i}$, as well as sampling points for the gas flow (samplers)

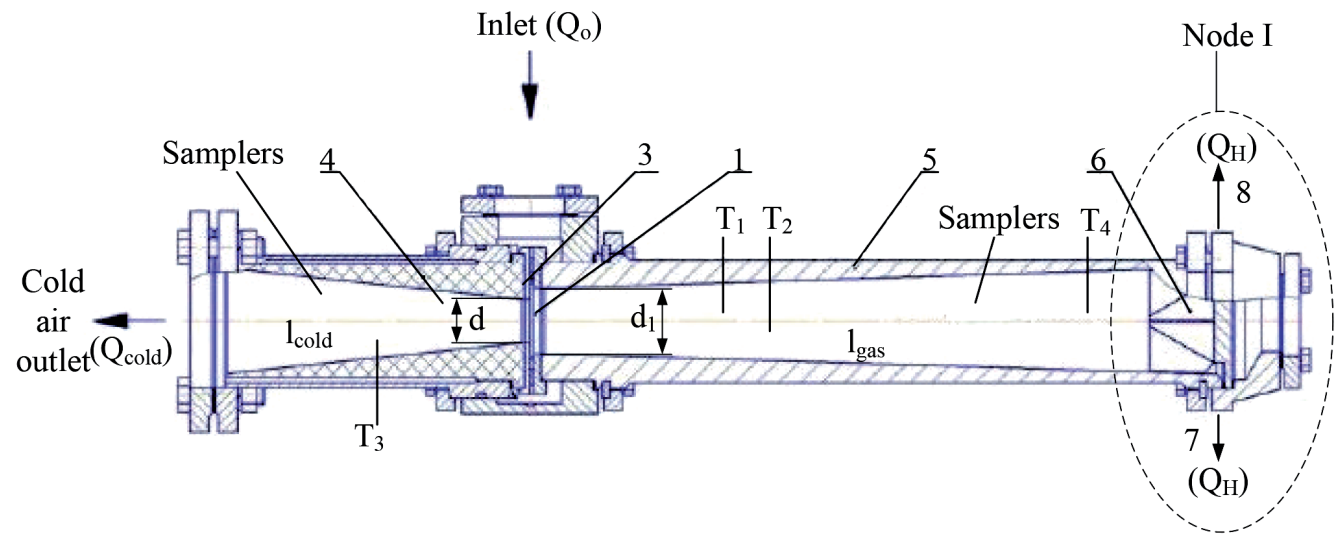

Fig. 2. Scheme of the vortex tube ЧКЗ-ЮГСОН:

1 - annular swirler; 2 - zone of energy distribution; 3 - diaphragm; 4 - cold gas outlet chamber $\left(Q_{C}\right)\left(l_{H} / d_{1} \approx 10\right)$;

5 - chamber of quasipotential flow zone $\left(Q_{H}\right)\left(I_{H} / d_{1} \approx 10\right) ; 6$ - throttle valve, regulating the ratio $\left(Q_{C} / \emptyset_{H}\right) ; 7$ - boundary layer, which is saturated with aerosol; 8 - near-axial flow of pure gas. 5 - sampler, $T_{i}$ - temperature measurement cites 


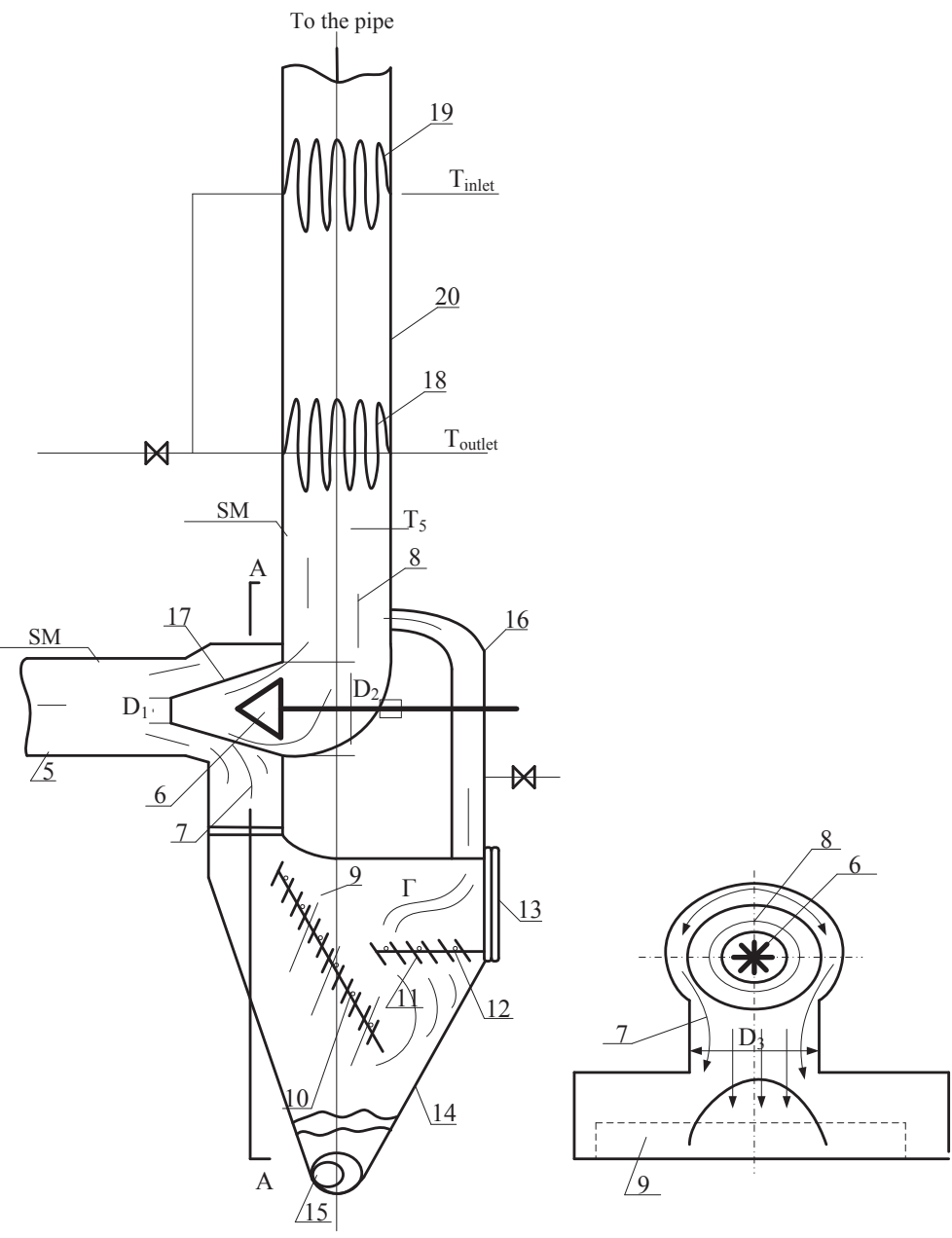

Fig. 3. The diagram of the node (Fig. 2, pos. 1):

5, 6, 7, 8 - corresponds to the ones indicated in Fig. 1; 9 - a block of plate reflectors with a mechanism 10 for controlling the angle of attack (item 9); 11, 12 - also the same

as 9, 10; 13 - service hatch; 14 - bunker; 15 - unloading auger; 16 - purified gas pipeline; 17 - cone-pipeline for the removal of clean gas. $5 M$ - samplers,

$T_{i}$ - temperature measurement points

The measuring points $T_{1}$ and $T_{2}$ were 1.8 caliber away from the wall of the vortex chamber (Fig. 1), and $T_{4}$ at a distance of 6.5 caliber. The diameter of the working part of the cylinder for the sensors $\left(T_{i}\right.$ and $S$ ) was $6 \cdot 10^{-3} \mathrm{~m}$.

As is known from [17], the influence of the sensor on the distribution of the velocity field is insignificant, especially at high gas flow rates, i. e. at high speeds. In carrying out the experimental studies, the vortex tube (Fig. 1) and (Fig. 2, pos. 14, 16, 20) was thermally insulated, the temperature on the insulation surface during the operation of the installation did not exceed 313-323 K.

The dust concentration in the gas flow was determined by a ПО-2 dust sampler (Russia), and the concentration of gaseous oxides was determined by a УГ-2 universal gas analyzer (Ukraine). Thermocouples XA (273-1173 K) (Russia) were used as temperature sensors. The pressure of the gas-air mixture before inlet in the tube was determined by the instrument НМП-52 (0-40 mbar) (Russia), the velocity of the gas-dust flow was determined with the help of the gas analyzer Тест $350 \mathrm{M} / \mathrm{XL}$ No. 412 (Russia). The dust extracted from the sample was studied using the УРC-50ИМ diffractometer (Russia) using a nickel filter at $17 \mathrm{kV}$ and a current of $3.5 \mathrm{~mA}$. Thermal analysis of the dust samples was carried out on the MOM Q1500 derivato- graph (Hungary). The weight on the specimen $100 \mathrm{mg}$, dish-shaped platinum crucibles, the heating rate was $10 \mathrm{deg} / \mathrm{min}$, and the maximum temperature was $1473 \mathrm{~K}$. The dust particle size was measured and the structure was determined on an electron microscope УEMB-100 (Ukraine) and on a Siemens electric scanning microscope «Elmiskop-1» (Germany).

The distribution of dust particles by size was calculated on the basis of the multimodal distribution function in the form [18]:

$$
f(x)=\sum_{i=1}^{n} W_{i} f_{i}(x)
$$

or in the expanded form:

$$
\begin{gathered}
f(x)=\frac{W\left(x-x_{\min }\right)^{a_{1} m_{1}}\left(x_{\max }-x\right)^{m_{1}}}{\int_{x_{\min 1}}^{x_{\max }}\left(x-x_{\text {min }_{1}}\right)^{a_{1} m_{1}}\left(x_{\max _{1}}-x\right)^{m_{1}} d x}+ \\
+\frac{(1-W)\left(x-x_{\text {min }_{2}}\right)^{a_{2} m_{2}}\left(x_{\max _{2}}-x\right)^{m_{2}}}{\int_{x_{\min 2}}^{x_{\max 2}}\left(x-x_{\min _{2}}\right)^{a_{2} m_{2}}\left(x_{\max _{2}}-x\right)^{m_{2}} d x}
\end{gathered}
$$

where $x$ - the absolute size; $x_{\min }, x_{\max }$ - the smallest and the largest, the indices $(1,2)$ refer to the fine and coarse fractions; $W-$ the mass fraction of fine particles; $(1-W)-$ the mass fraction of the coarse fraction.

During the study, sampling and analysis of gases in the ducts before and after the vortex tube was performed by the plant's central laboratory (PCL).

\section{Research results}

At the inlet to the vortex tube, the following indicators were recorded during the research (Table 1).

Table 1

\begin{tabular}{|c|c|c|c|c|c|}
\hline No. & $\begin{array}{l}\text { Toxic } \\
\text { sub- } \\
\text { stance }\end{array}$ & $\begin{array}{l}\text { Concentration of } \\
\text { the substance at } \\
\text { the inlet, } \mathrm{mg} / \mathrm{Nm}^{3}\end{array}$ & $\begin{array}{c}\text { Gas pго- } \\
\text { ductivity, } \\
\mathrm{Nm}^{3} / \mathrm{h}\end{array}$ & Dust & $\begin{array}{l}\text { Dust concen- } \\
\text { tration on the } \\
\text { flow, } \mathrm{mg} / \mathrm{Nm}^{3}\end{array}$ \\
\hline \multirow{2}{*}{1} & \multirow{2}{*}{ СО } & $\begin{array}{l}100 \\
110 \\
120\end{array}$ & 1500.0 & \multirow{4}{*}{$\begin{array}{c}\text { A } \\
\text { mixture } \\
\text { of dust } \\
\text { particles } \\
\text { Zn and } \\
\text { ZnO }\end{array}$} & $\begin{array}{l}1829.0 \\
2714.0 \\
2905.0\end{array}$ \\
\hline & & $\begin{array}{c}118 \\
95 \\
120\end{array}$ & 3000.0 & & $\begin{array}{l}4470.0 \\
2762.0 \\
2435.0\end{array}$ \\
\hline \multirow{2}{*}{2} & \multirow{2}{*}{$50_{2}$} & $\begin{array}{l}80 \\
21 \\
36 \\
\end{array}$ & 1500.0 & & $\begin{array}{l}- \\
- \\
-\end{array}$ \\
\hline & & $\begin{array}{l}38 \\
28 \\
50\end{array}$ & 3000.0 & & $\begin{array}{l}- \\
- \\
-\end{array}$ \\
\hline \multirow{2}{*}{3} & \multirow{2}{*}{$\mathrm{NO}_{x}$} & $\begin{array}{l}70 \\
69 \\
65\end{array}$ & $\begin{array}{l}- \\
- \\
-\end{array}$ & $\begin{array}{l}- \\
- \\
-\end{array}$ & $\begin{array}{l}- \\
- \\
-\end{array}$ \\
\hline & & $\begin{array}{l}70 \\
70 \\
70\end{array}$ & $\begin{array}{l}- \\
- \\
-\end{array}$ & $\begin{array}{l}- \\
- \\
-\end{array}$ & $\begin{array}{l}- \\
- \\
-\end{array}$ \\
\hline
\end{tabular}

Indicators of the amount of dust and concentration of toxic substances in the gas flow after melting furnaces at the inlet to the vortex tube 
Fig. 4 shows the distribution curves for the size of dust particles at the inlet to the vortex tube.

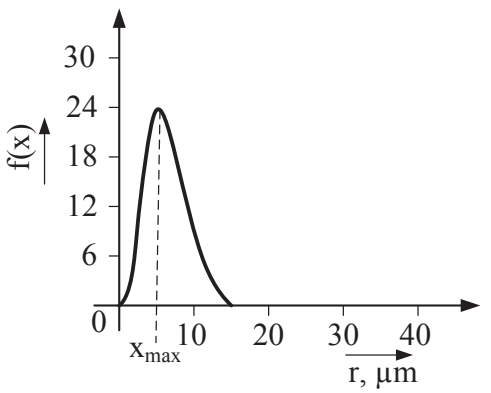

Fig. 4. The distribution curves for the size of dust particles at the inlet to the vortex tube

As can be seen from the graphs in Fig. 4, the bulk of the dust particles has a size in the range of from 5 to $10 \mu \mathrm{m}$. X-ray phase analysis of dust samples at the inlet, as well as thermographic analysis of differential thermal analysis (DTA), differential thermogravimetric (DTG) indicate that the bulk of dust particles is a $Z_{n}$ powder, in some cases these zinc particles are coated with an oxide film. The micrographs of the zinc powder are shown in Fig. 5.
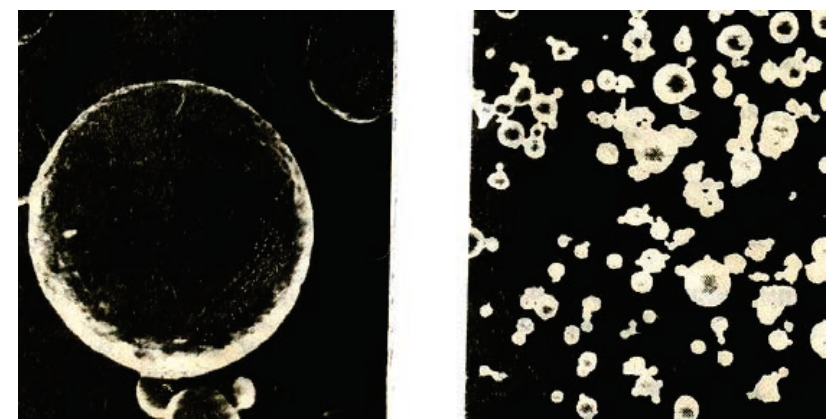

Fig. 5. Micrographs of zinc powder at the inlet to the vortex tube

As can be seen from the photographs in Fig. 5, the dust particles at the inlet to the vortex tube are represented in the form of beads with dimensions from 5 to $10 \mu \mathrm{m}$.

The specific surface area of the zinc powder, which was determined by the «БЭТ» method, was from 2 to $3 \mathrm{~m}^{2} / \mathrm{g}$.

Further Fig. 6 shows the results of observations of the vortex tube functioning from the change in the temperature of the gas flow according to the measurement points (Fig. 2, 3).

As shown by the results of the measurement of temperatures (Fig. 6), the distribution of the braking temperatures on the annular boundary at different distances from the vortices and at various rate of $Q_{A}$, that is, the indirect intensity of the swirl of the flow, is observed. Thus, the temperature difference in the zone of a quasisolid swirling flow $\left(T_{1}, T_{2}\right)$ reaches about $35^{\circ} \mathrm{C}$ at a rate of $Q_{A}=1500 \mathrm{Nm}^{3} / \mathrm{h}$ at about $35^{\circ} \mathrm{C}$. With further distance from the swirling $\left(T_{4}\right)$, the temperature braking profile becomes stable and at the point $T_{4}$ of the difference reaches $18{ }^{\circ} \mathrm{C}$. At a rate of $Q_{A}=3000 \mathrm{Nm}^{3} / \mathrm{h}$, respectively, the difference is from 40 to $45^{\circ} \mathrm{C}$, and $T_{4}=25^{\circ} \mathrm{C}$. These results indicate an uneven distribution of velocities along the tube radius, leading to intense dissipation of mechanical energy, internal heat generation and distri- bution of the braking temperature. Similar dependences are observed under the conditions (Fig. 6), when water vapor was applied to the input gas flow. The amount of water vapor was taken from the ratio of the mass of water vapor (mg) to the composition of the gas toxicants $\left(\mathrm{CO} ; \mathrm{NO}_{x} ; \mathrm{SO}_{2}\right) \mathrm{mg}($ Table 1$)=10$. The mass of the toxicants was about $220 \mathrm{mg}$, that is, the $\mathrm{H}_{2} \mathrm{O}$ rate was approximately $2200-3000 \mathrm{mg} / \mathrm{Nm}^{3}$. Water vapor was added to the gas flow to provide possible homogeneous reactions in which water vapor is a catalyst:

$$
\begin{aligned}
& \mathrm{CO}+\mathrm{H}_{2} \mathrm{O} \rightarrow \mathrm{CO}_{2}+\mathrm{H}_{2}, \\
& 2 \mathrm{H}_{2}+\mathrm{O}_{2} \rightarrow 2 \mathrm{H}_{2} \mathrm{O}, \\
& 2 \mathrm{NO}+\mathrm{O}_{2} \rightarrow 2 \mathrm{NO}_{2}, \\
& \mathrm{NO}_{2}+\mathrm{SO}_{2} \rightarrow \mathrm{NO}+\mathrm{SO}_{3}, \\
& \mathrm{CO}+\mathrm{SO}_{2} \rightarrow 2 \mathrm{CO}_{2}+1 / 2 \mathrm{~S}_{2} .
\end{aligned}
$$

Calculations of $\Delta G$ of these reactions by the procedure of [19] proved that such reactions can occur at temperatures above $693 \mathrm{~K}$ in the presence of water vapor.

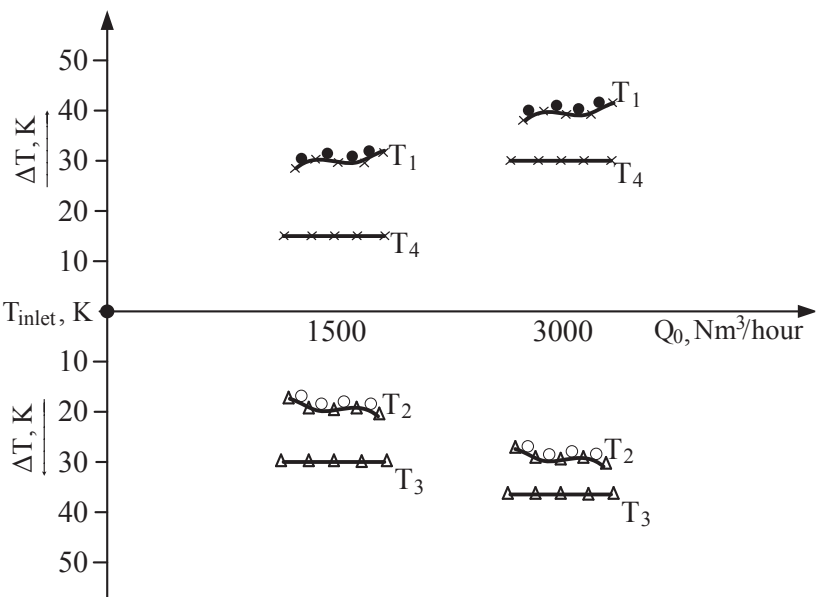

Fig. 6. The results of measuring the temperature with the mobility of the disperse flow in the vortex tube: $T_{1}, T_{2}, T_{3}, T_{4}$ - correspondence to the measuring points in Fig. 2 ; $\bullet, \circ-$ points $T_{1}, T_{2}$ under the conditions when compressed water vapor is added to the inlet of the gas flow in an amount corresponding to the ratio $M_{\mathrm{H} 2 \mathrm{O}} / \Sigma M_{T}\left(\mathrm{CO}, \mathrm{NO}_{x_{1}}, \mathrm{5O}_{2}\right) \approx 10$ at a pressure of $2 \cdot 10^{5} \mathrm{~Pa}, T_{f}=513 \mathrm{~K}$

Fig. 7 shows the distribution curve for the size of the dust particles at the outlet from the vortex tube 5 and before the inlet to the bunker 14 in Fig. 3.

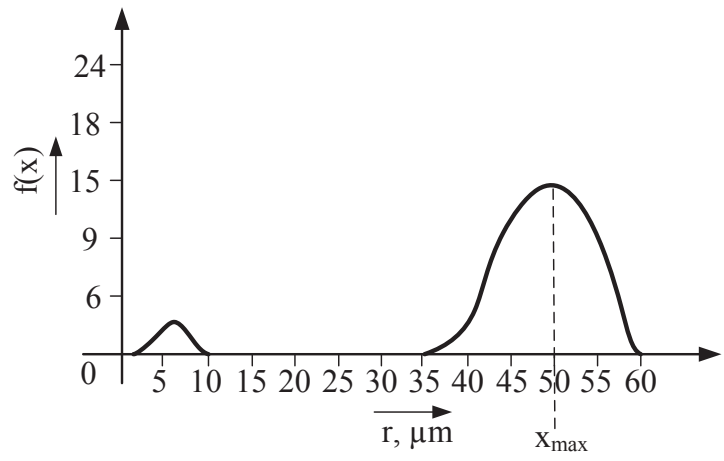

Fig. 7. Distribution curves for the size of dust particles at the outlet of the vortex tube 
As can be seen from Fig. 7, the bulk of the dust particles has a size in the range of from 45 to $55 \mu \mathrm{m}$. The micrographs of the powder are shown in Fig. 8.

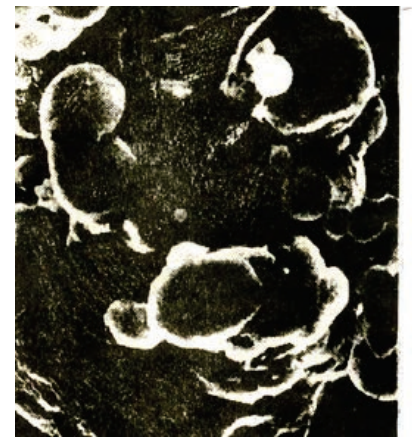

a

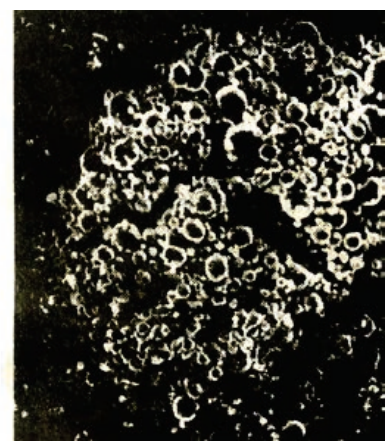

$b$
Fig. 8. Microphotographs of the powder at the outlet of the vortex tube: $a$ - zone of quasi-solid flow of the gas flow; $b$ - zone of quasipotential flow of the gas flow

Fig. 8 shows that in the zone of quasi-solid flow of the gas flow after the swirler and further in the zone of the quasipotential flow of the gas flow to the outlet from the tube (hot end), agglomeration of the dust particles passes through energy dissipation. This is due to high-speed collisions of particles among themselves, while agglomerates with a size of about $50 \mu \mathrm{m}$ are created. In this case, the bulk of the agglomerates are concentrated around the wall of the tube, and most of the gas molecules in the center of the working chamber. Therefore, the dusty gas flow moves along the walls of the tube, exits through the annular opening between the tube body 5 and the body 17 (Fig. 3). After that, falls into the bunker 14, in which the blocks of reflectors pos. 10 12. Due to a sharp change in the flow direction, intensive separation takes place with the removal of dust particles. The cleaned gas moves along the center of the vortex tube 5 (Fig. 3) through the opening in the body 17 and the annular opening between the body 17 and the throttle, into the chamber 20, the purified gas from the bunker 14 is fed to the same chamber via the pipeline 16 . The chamber 20 is equipped with heat exchange devices 18, 19 for the utilization of the heat of the purified gas before the gas is supplied to the tube for emission into the atmosphere.

Table 2 shows the amount of dust and concentration of toxic substances in the gas flow at the outlet of the vortex tube after the bunker.

Quality indicators for exhaust gas purification in a vortex tube

\begin{tabular}{|c|c|c|c|c|c|c|}
\hline $\begin{array}{c}\text { Toxic } \\
\text { substance }\end{array}$ & $\begin{array}{c}\text { Concentra- } \\
\text { tion of toxic } \\
\text { substance, } \\
\mathrm{mg} / \mathrm{Nm}^{3}\end{array}$ & $\begin{array}{l}\text { Gas flow rate } \\
\text { at the inlet } \\
\text { in the tube, } \\
\mathrm{Nm}^{3} / \mathrm{hour}\end{array}$ & $\begin{array}{l}\text { Purification } \\
\text { efficiency, } \\
\% \text { relative to } \\
\text { Table } 1\end{array}$ & Dust & $\begin{array}{c}\text { Dust con- } \\
\text { centration } \\
\text { in the flow, } \\
\mathrm{mg} / \mathrm{Nm}^{3}\end{array}$ & $\begin{array}{l}\text { Purification } \\
\text { efficiency, } \\
\text { \% relative to } \\
\text { Table } 1\end{array}$ \\
\hline \multirow{2}{*}{ СО } & 11.0 & 1500.0 & 89.5 & \multirow{6}{*}{$\begin{array}{c}\text { ZnD } \\
\text { particles } \\
\text { with } \\
\text { with zinc } \\
\text { impuri- } \\
\text { ties }\end{array}$} & 58.0 & 97.0 \\
\hline & 9.0 & 3000.0 & 90.4 & & 19.0 & 99.9 \\
\hline \multirow{2}{*}{$50_{2}$} & 3.0 & 1500.0 & 92.1 & & - & - \\
\hline & 2.0 & 3000.0 & 99.6 & & - & - \\
\hline \multirow{2}{*}{$\mathrm{NO}_{x}$} & 13.0 & 1500.0 & 81.5 & & - & - \\
\hline & 11.0 & 3000.0 & 83.1 & & - & - \\
\hline
\end{tabular}

Note: purification efficiency is given as the mean value over the period of operation according to the PCL data.
As can be seen from the data given in Table 2, when implementing the purification process of exhaust gases in a vortex tube, not only the processes of agglomeration of dust are observed, but also the destruction of gas toxicants. The previous value of performance indicators depends on the intensity of the flow swirl.

Fig. 9 shows the characteristics of the change in the concentration of aerosols at the outlet of the cooled gas (chamber 4 in Fig. 2) and at the outlet of the heated flow (5, SM in Fig. 3) under various modes of vortex tube functioning as a function of parameter $\ll B »$ (equation (1)).

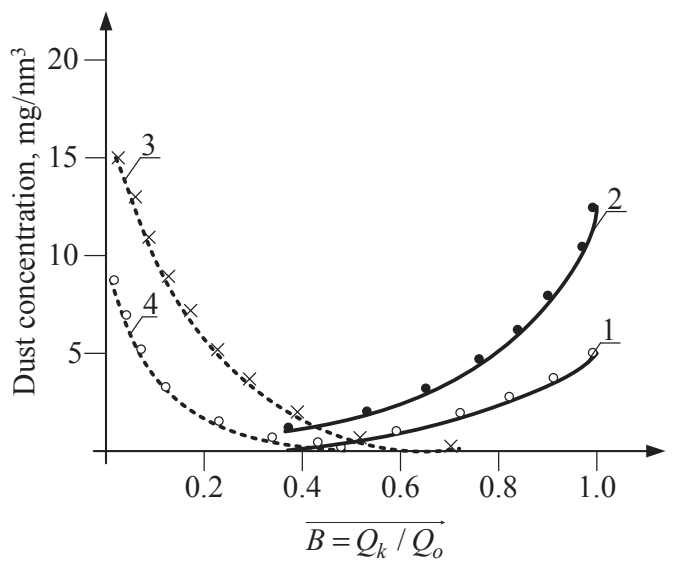

Fig. 9. The nature of the change in the aerosal concentration at the outlet of the vortex tube for different values of the parameter $« B »$ :

1,4 - at a gas productivity of $3000 \mathrm{Nm}^{3} / \mathrm{h} ; 2,3$ - at a gas productivity of $1500 \mathrm{Nm}^{3} / \mathrm{h} ; 1,2$ - dust concentration of the cool gas; 3, 4 - dust concentration of hot gas

As the data shown in Fig. 9, with increasing parameter «B», the initial dust concentration of the cooled flow (curves 1,2) increases. At the same time, the lowest dust concentrations in the cold flow are observed at the maximum flow rates $Q_{A}$, that is, the gas flow rate at the inlet to the tube. According to the hot section, then with an increase in the parameter $« B »$, a decrease in the aerosol concentration is observed, a significant decrease in the aerosol concentration is also observed at the maximum values of $Q_{4}$.

The data presented in Fig. 9 are important for practice when using vortex tubes as aerosol separators, since they allow choosing the necessary mode of removal of ash particles from the bearing center. The minimum aerosol yield is observed in the parameter range $« B »$ from 0.3 to 0.6 . The minimum value of the initial concentration of aerosol is achieved at $\langle B »=0.4$. It should also

Table 2 be noted that the average particle size of the dust particles exits with a cold flow is less than $5 \mu \mathrm{m}$.

The efficiency of using a vortex tube as an aerosol separator can be determined by the formula:

$$
\eta^{*}=\left\{1-\left[\frac{Z_{1}}{Z_{0}} B-\frac{Z_{2}}{Z_{0}}(1-B)\right]\right\} \cdot 100,
$$

where $Z_{0}$ - the input aerosol concentration, $\mathrm{mg} / \mathrm{Nm}^{3} ; Z_{1}-$ aerosol concentration at the outlet of cold flow, $\mathrm{mg} / \mathrm{Nm}^{3} ; Z_{2}-$ aerosol concentration at the outlet of the hot flow, $\mathrm{mg} / \mathrm{Nm}^{3}$. 
With an inlet concentration of $Z_{0}=3000 \mathrm{mg} / \mathrm{Nm}^{3}, B=0.45$. $Z_{1}$ and $Z_{2}$, respectively (Fig. 9), with a gas productivity of 1500 and $3000 \mathrm{~nm}^{3} / \mathrm{h}$, respectively, is about $97.9 \%$ and $99.96 \%$, which correlates with the data given in Table 2 .

In studies of gas productivity at 1500 and $3000 \mathrm{Nm}^{3} / \mathrm{h}$ at the inlet, a portion of the purified gas after the bunker 14 was withdrawn to the swirler before feeding (Fig. 3, pos. 16). The amount of gas was $10-20 \%$ of the volume of the gas flow that left the hopper, in order to determine the effect of recirculation of the hot flow on the dust collection process.

Fig. 10 shows the dependence of the purification efficiency on the total gas consumption and gas consumption with recirculation.

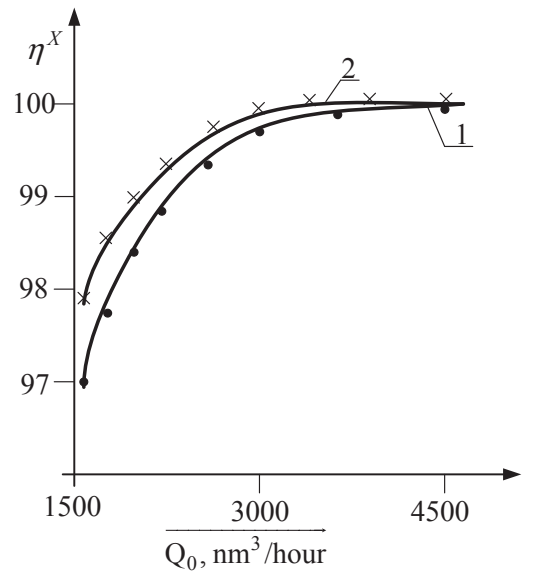

Fig. 10. Dependence of purification efficiency on total gas consumption and gas consumption with recirculation: 1 - no recirculation; 2 - recirculation of $20 \%$

As the data in Fig. 10, the recirculation of hot gas increases the purification efficiency with low exhaust gas efficiency at the inlet to the vortex tube. This phenomenon is obviously connected with the growth of the composite flow $Q_{4}$.

The analysis of the obtained results of dust collection research in vortex tubes testifies to the advisability of using such devices as highly efficient dust collectors for dry gas purification and use of their waste thermal energy. The latter is shown schematically in this work, since the choice of heat exchange equipment (Fig. 3, pos. 18-20) and its calculations have been thoroughly considered in [20,21] The above experimental studies in vortex tubes compared with the best of the existing apparatus - the centrifugal cyclone ЦН-11 (Ukraine) allows to state a significant (up to 6-9\%) increase in the efficiency of collecting fine dust in the proposed dust-purification system. This opens up prospects for the introduction of vortex tubes and vortex chambers and helps to reduce the industrial negative impact on the atmosphere. Important is the issue of reducing the threat of global consequences for future generations through engineering solutions to prevent the release of fine aerosols.

\section{SWOT analysis of research results}

Strengths. The analysis of the obtained results of dust collection research in vortex tubes testifies to the advisability of using such devices as highly efficient dust collectors for dry gas purification and use of their waste thermal energy.

When implementing the process of purification of exhaust gases in a vortex tube, not only the processes of agglomeration of dust are observed, but also the destruction of gas toxicants.

Weaknesses. In the paper, various methods for the decay of the forces of gas flows are considered. The following is revealed:

- cyclones of various designs can't capture dust particles less than $20 \mu \mathrm{m}$;

- wet dust collectors are complex constructively, require significant energy costs, and also require the use of water depending on the type of dust collector;

- as a result of operation, significant amounts of industrial effluents are generated, which must be disposed of using additional equipment.

Opportunities. The opportunities for the introduction of vortex tubes and vortex chambers are opened and the possibility of reducing the industrial negative influence on the atmosphere. Important is the issue of reducing the threat of global consequences for future generations through engineering solutions to prevent the release of fine aerosols.

Threats. It is proved that in the vortex tubes, in comparison with the existing centrifugal cyclone ЦН-11, a significant (up to 6-9 \%) increase in the efficiency of trapping fine dust is observed. This opens up prospects for the introduction of vortex tubes and vortex chambers and helps to reduce the industrial negative impact on the atmosphere. The enterprise will need to increase the capital costs for installing new equipment for purification. Capital costs for the introduction of a dust collector are disposable.

\section{Conclusions}

1. The process of dry dust purification of exhaust gases produced by zinc white after the melting furnaces of metallic zinc in a vortex tube under aerodynamic conditions is studied, which leads to the occurrence of Rank effect. It is proved that the behavior of the gas-dispersed flow under investigation during flow in a vortex tube is the same as for a gas flow without an aerosol. That is, two types of flow of the gas-dispersed flow are observed after it is twisted along the tube, depending on the zone, is considered. Also, the effect of the redistribution of the total energy in the wrapped flow and, accordingly, the change in the dynamic structure of the flow is observed.

2. It is experimentally established that agglomeration of aerosol particles due to high-speed collisions of particles is observed in the vortex tube in the zone of quasi-solid rotation, where the most intense redistribution of energy and temperature is observed. The resulting agglomerates are almost 10 times larger than the dust particles that are fixed at the inlet to the vortex tube. The purification efficiency achieved is $97.8-99.9 \%$, depending on the gas flow rate at the inlet to the tube.

3. No less important research result is that the possibility of catalytic destruction of gas impurities $\left(\mathrm{CO}, \mathrm{NO}_{x}\right.$, $\left.\mathrm{SO}_{2}\right)$ is proved when adding water vapor as a catalyst to the gas flow at the inlet of the tube. As a result, the purification rate is: $\mathrm{CO}=90.0 \%, \mathrm{SO}_{2}=92.0-99.0 \%$, $\mathrm{NO}_{x}=81.0 \%$. 
4. The dependence of the vortex tube utilization efficiency as a separator on various factors such as recirculation of purified hot gas and its part, parameter $\left\langle B »=Q_{C} / Q_{A}\right.$, and other parameters is investigated. The advantages of a vortex tube as a separator over cyclones are proved. Studies in vortex tubes compared with the best of the existing apparatus - the centrifugal cyclone ЦН-11 allows to affirm a significant (up to 6-9 \%) increase in the efficiency of fine dust collection in the proposed dust-purification system. This opens up prospects for the introduction of vortex tubes and vortex chambers and helps to reduce the industrial negative impact on the atmosphere.

In general, the above-mentioned allows to conclude that the aim of research is achieved. The obtained data can be used in studies of similar disperse systems.

\section{References}

1. Zlygostev, A. S. Metody ochistki i obezvrezhivaniia ventiliatsionnyh i tehnologicheskih vybrosov [Electronic resource] / A. S. Zlygostev // Zelenaia planeta. - 2010. - 20 p. - Available at: \www/URL: http://ecologylib.ru/

2. Chekalov, L. V. Zashchita atmosfernogo vozduha ot vybrosov pyli, aerozolei i tumanov [Text] / L. V. Chekalov. - Yaroslavl: Rus, 2004. - 424 p.

3. Zaretskii, A. D. Promyshlennye tehnologii i innovatsii [Text] / A. D. Zaretskii, T. E. Ivanova. - St. Petersburg: Piter, 2014. $480 \mathrm{p}$.

4. Batluk, V. A. Zalezhnist efektyvnosti pylovlovlennia vidtsentrovo-inertsiinykh aparativ vid konstruktsii bunkera [Text] / V. A. Batluk, M. V. Basov et al. // Promyslova hidravlika i pnevmatyka. - 2009. - Vol. 3, No. 25. - P. 40-43.

5. Batluk, V. A. Zalezhnist efektyvnosti pylovlovlennia vidtsentrovo-inertsiinykh aparativ vid konstruktsii bunkera [Text] / V. A. Batluk, O. V. Melniko, O. V. Mirus // Promyslova hidravlika i pnevmatyka. - 2011. - Vol. 2, No. 32. - P. 44-47.

6. Liapkov, A. A. Tehnika zashchity okruzhaiushchei sredy [Text]: Handbook / A. A. Liapkov, E. I. Ionova. - Ed. 2. - Tomsk: Tomsk Polytechnic University, 2008. - 317 p.

7. Aslamova, V. S. Avtomatizirovannaia sistema issledovaniia tsiklonov i skrubberov [Text] / V. S. Aslamova, A. A. Zhabei // Izvestiia Tomskogo politehnicheskogo universiteta. Inzheniring georesursov. - 2010. - Vol. 3016, No. 1. - P. 71-76.

8. Kutepov, A. M. Vihrevye protsessy dlia modifikatsii dispersnyh sistem [Text] / A. M. Kutepov, A. S. Latkin. - Moscow: Nauka, 1999. - 270 p.

9. Gao, J. Simulations of gas-liquid-solid 3-phase flow and reaction in FCC riser reactors [Text] / J. Gao, C. Xu, S. Lin, G. Yang, Y. Guo // AIChE Journal. - 2001. - Vol. 47, No. 3. P. 677-692. doi:10.1002/aic.690470315

10. Veretennikov, S. V. Experimental investigation of heat transfer in energy separation chambers of the vortex tube [Text] / S. V. Veretennikov, S. N. Barinov // VESTNIK of the Samara State Aerospace University. - 2015. - Vol. 14, No. 2. P. 44-51. doi:10.18287/2412-7329-2015-14-2-44-51

11. Luo, G. Numerical simulation of gas-particle flows with different swirl numbers in a swirl burner [Text] / G. Luo, R. Li, L. Zhou // Tsinghua Science and Technology. - 2000. - Vol. 5, No. 1. - P. 96-99.

12. Deich, M. E. Tehnicheskaia gazodinamika [Text] / M. E. Deich. Ed. 3. - Moscow: Energiia, 1974. - 592 p.

13. Molochko, F. I. O sushchnosti vihrevogo effekta Ranka-Hil'sha [Text] / F. I. Molochko // Problemy zahalnoi enerhetyky. 2015. - Vol. 4, No. 43. - P. 58-60.
14. Burov, O. O. Dedusting gas emissions drying plant [Text] / O. O. Burov, A. I. Burov, L. V. Vinogradenko // Ahrarnyi visnyk Prychornomoria. - 2014. - Vol. 74. - P. 140-143.

15. Maslov, V. E. Pylekontsentratory v topochnoi tehnike [Text] / V. E. Maslov. - Moscow: Energiia, 1977. - 285 p.

16. Piralishvily, S. A. Vortex effect and intensification of heat and mass transfer in cell energy technology [Text] / S. A. Piralishvily, S. V. Veretennikov // VESTNIK of Samara University. Aerospace And Mechanical Engineering. - 2011. - No. 3-1 (27). P. 241-247.

17. Pitak, I. V. Issledovanie mokrogo protsessa ulavlivaniia pyli v rotornom vihrevom apparate [Text] / I. V. Pitak // Bulletin of the National Technical University «KhPI» Series: New solutions in modern technologies. - 2010. - No. 17. - P. 135-140.

18. Civan, F. Reservoir Formation Damage [Text] / F. Civan. Ed. 3. - Elsevier, 2016. - 1042 p. doi:10.1016/c2014-0-01087-8

19. Karapetiants, M. H. Himicheskaia termodinamika [Text] / M. H. Karapetiants. - Moscow: Himiia, 1975. - 584 p.

20. Rotary mass-exchange apparatus [Electronic resource]: Patent UA 29985 U, МПК (2006) B01D 3/00 / Pitak I. V., Troshyn O. H., Moiseiev V. F., Shaporev V. P. - Appl. No. u200708025; Filed 16.07.2007; Publ. 11.02.2008. - Available at: \www/URL: http:// uapatents.com/2-29985-rotornijj-masoobminnijj-aparat.html

21. Tovazhnianskyi, L. L. Mashyny i aparaty u khimichnykh, kharchovykh i pererobnykh vyrobnytstvakh [Text] / L. L. Tovazhnianskyi, V. P. Shaporev, I. V. Pitak et al. - Kharkiv: Kolehium, 2011. -610 p.

\section{ИССЛЕДОВАНИЕ ФУНКЦИОНИРОВАНИЯ ВИХРЕВОЙ ТРУБЫ ЛРИ ПОДАЧЕ В ТРУБУ ДИСЛЕРСНОГО ПОТОКА (ГАЗ - ЧАСТИЧКИ пыли)}

Исследовано функционирование вихревых труб для процесса сухой очистки выхлопных газов от аэрозоля, в которых аэродинамическая ситуация приводит к возникновению эффекта Ранка. Исследован процесс «сухой» пылеочистки и его теоретическое обоснование с учетом параметров: геометрии и конструкции аппарата; входных параметров газового потока и химического состава частиц; возможности химического взаимодействия с газовыми компонентами.

Ключевые слова: сухая очистка выхлопных газов от аэрозоля, эффект Ранка, выхлопная труба.

Shaporev Valery, Doctor of Technical Sciences, Professor, Department of Chemical Technique and Industrial Ecology, National Technical University «Kharkiv Polytechnic Institute», Ukraine, ORCID: http:// orcid.org/0000-0003-1652-4688

Pitak Inna, PhD, Associate Professor, Department of Chemical Technique and Industrial Ecology, National Technical University «Kharkiv Polytechnic Institute»,Ukraine,e-mail: ipitak5@gmail.com, ORCID: http:// orcid.org/0000-0002-5073-2942

Pitak Oleg, PhD, Associate Professor, Department of Labour Protection and the Environmental, National Technical University «Kharkiv Polytechnic Institute», Ukraine, ORCID: http://orcid.org/0000-00015912-4604

Briankin Serhii, Head of Course of the Faculty of Military Training, National Technical University «Kharkiv Polytechnic Institute», Ukraine, e-mail: serzh2082@ukr.net, ORCID: https://orcid.org/00000003-0444-9107 